\title{
An Examination Into the Causal Links Among Inward FDI Determinants: Empirical Evidence From Jordan
}

\author{
Mohamed Ibrahim Mugableh ${ }^{1}$ \\ ${ }^{1}$ Department of Finance \& Banking Science, College of Administrative \& Financial Sciences, Irbid National \\ University, Jordan \\ Correspondence: Mohamed Ibrahim Mugableh, Head Department of Finance \& Banking Science, College of \\ Administrative \& Financial Sciences, Irbid National University, Jordan. Tel: 962-790-956-497.
}

Received: September 11, 2020

Accepted: November 4, 2020

Online Published: January 14, 2021

doi:10.5430/ijfr.v12n2p195

URL: https://doi.org/10.5430/ijfr.v12n2p195

\begin{abstract}
This paper examined the causal links between inward foreign direct investments (FDI) and its determinants (i.e., gross domestic product, education, trade openness, infrastructure, and technological abilities) for Jordan over (the period 1980 - 2018). The paper used vector error correction model. The results of the study considered that gross domestic product, trade openness, education, infrastructure, and technological abilities are primary engine of inward FDI in (long term and short term). Thus, the results have vital role for the policy makers in Jordan to formulate domestic and foreign policies. This study relied on three essential parts. Firstly, FDI is a significant source of capital that promotes economic growth. Secondly, the question of what are the leading drivers of FDI remains inadequate in the literature. Finally, this research adds to the literature by using different econometrics techniques and long span of yearly time series data.
\end{abstract}

Keywords: inward FDI determinants, Jordan, time-series analysis, VECM

JEL Classification: F43, G11, C32

\section{Introduction}

There are many reasons behind the attraction of foreign capitals such as (1) low tax rates (2) macroeconomic stability (3) low levels of corruption and bureaucracy and (4) flexibility in the legislative system. However, there should be inward foreign direct investment (FDI) because of their benefits in increasing economic development in the host country and creating new job opportunities. In addition, it has indirect effects, such as new management, technology transfer, and new production systems.

Therefore, it is necessary to focus on the issue of inward FDI because it is considered a basic pillar for developing countries that face a great shortage of domestic resources in order to accelerate economic development. Thus, studying the determinants of inward FDI in Jordan is imperative for modeling an effective macroeconomic policy to attract FDI inflows. In addition, this paper will discuss several aspects:

Firstly, inward FDI in economies is widely reported in the literature because it is an important and stable source of capital that promotes economic development (Lien \& Filatotcher, 2015; Iwasaki \& Tokunaga, 2016; Beckmann \& Czudaj, 2017; Kayalvizhi \& Thenmozhi, 2018; Lee, Alba \& Park, 2018; Li, Quan, Stonia \& Azar, 2018; Cui \& Xu, 2019; Dellis, Sondermann \& Vansteenkiste, 2020; Hou, Li, Li \& Ouyang, 2020; Sadeghi, Shahrestani, Kiani \& Torabi, 2020). Secondly, the main drivers of inward FDI were investigated, because previous literature did not provide sufficient information on this topic. Finally, this research contributes to filling this gap by using different econometrics techniques and long span of yearly time - series data over (the $1980-2018$ period). However, sections of this paper are divided as follows. In the first section, the theoretical background and review of previous literature are explained. In the second section, an overview of the Jordanian economy is summarized. In the third section, the methodology and results analysis are discussed. In the final section, summary and some policy implications are given. 


\section{Theoretical Background and Literature Review}

\subsection{Theoretical Background}

The main objective of seeking FDI is the availability of native natural resources, raw materials, and well trained employees. This is what is mentioned by Dunning (1993) when he classified the determinants of FDI into four parts: (1) seeking of market (2) seeking of resources (3) seeking of efficiency and (4) seeking of motives.

The goal of attracting FDI is to obtain networks that depend mainly on building the maximum cost effective and largest universal production networks. These networks are based on reducing production costs, which are: labor costs, transportation costs and raw material costs. However, the motives seeking or ownership advantages seeking FDI is related with the companies that have significant ownership advantages (i.e., brands, technological products, and research and development expertise).

\subsection{Literature Review}

Bilgili, Tuluce and Dogan (2012) examined the determinants of inward FDI in Turkey. The outcomes showed that the factors of inward FDI (i.e., gross domestic product (GDP) growth, labor cost, and the electricity price growth) significantly influenced inward FDI. Belloumi (2014) examined the association among inward FDI, trade openness, and economic growth in Tunisia for (the $1970-2008$ period). The study used autoregressive distributed lag (ARDL) approach and vector error correction model (VECM). The results showed the existence of a long-run relationship among variables.

As for Bekhet and Al-Smadi (2015) examined the (long-run and short-run) associations between inward FDI and its determinants (GDP, economic openness, money supply, consumer price index, and stock market index) in Jordan for (the 1978 - 2012 period). The paper employed ARDL approach and VECM. The results showed different equilibrium and causal relationships between inward FDI and its factors. Boateng, Hua, Nisar and Wu (2015) investigated the effect of macroeconomic variables on inward FDI in Norway. They used VECM and the outcomes showed that real GDP, trade openness, and exchange rate had positive effects on inward FDI. In addition, inflation rate, money supply, unemployment rate, and interest rate had negative effects. Kinuthia and Murshed (2015) examined the determinant of inward FDI in Kenya and Malaysia for (the 1960 - 2009 period) using VECM. The findings showed that Malaysia is more successful in attracting FDI compared to Kenya.

Abdouli and Hammami (2017) investigated the causal relations among FDI, environmental quality, and economic development for a group of 17 MENA countries. They used vector autoregressive (VAR) model for (the $1990-2012$ period). The results showed a unidirectional causality running from inward FDI to economic development. Elheddad (2018) examined the determinants of inward FDI using yearly panel data of six oil dependent countries (United Arab Emirates, Saudi Arabia, Qatar, Oman, Kuwait, and Bahrain). The results revealed that inward FDI is significantly influenced by different determinants. Vo (2018) examined the determinants of inward FDI (i.e., GDP, inflation rate, trade, stock market return volatility, and exchange rate volatility) in Vietnam. The results showed that inward FDI was significantly influenced by its determinants.

Economou (2019) investigated the effect of market size, economic freedom, fixed capital formation, and unit labor cost on inward FDI. The study covered four European counties (i.e., Spain, Portugal, Italy, and Greece) over (the 1996 - 2017 period). The results indicated positive influence of fixed capital formation, market size, and economic freedom on inward FDI. In addition, a negative consequence of unit labor costs was found on inward FDI. Muhammad and Khan (2019) investigated the determinants of economic growth using generalized method of moments in 34 Asian countries. The results revealed that FDI inflows and outflows, energy consumption, fixed capital formation, and carbon dioxide emissions affected economic development. Tsitouras, Mitrakos, Tsimpida, Vlachos, and Bitzenis (2019) examined the determinants of inward FDI (i.e., trade openness, education, infrastructure, technological abilities, and real GDP) in Greece for (the 1980 - 2016 period). The study employed VECM and the results indicated long-run relationships between variables.

\section{Jordan's Economic Overview}

According to the report of the World Bank (2019a), Jordan has implemented fundamental improvements that are, announcing new guidelines to manage aspects of financial dealings, such as liquidation, public procurement, and numerical payments. In doing so, Jordan is currently one of the top 20 performers in the World Bank's 2020 doing business report (World Bank, 2019a). Figure 1 shows that FDI started at a value of $1.88 \%$ in 1975 and remained increasing till the highest point in 2006 at a value of $23.5 \%$. After that, the FDI decreased dramatically in 2018 at a value of $2.24 \%$. Figure 2 displays that GDP registered the highest value in 2018 amounted to JD28.96 Billion. In fact, the crises in neighboring countries (i.e., Iraq and Syria) caused arrivals of refugees, greater education and health costs, 
and raise unemployment rates. The unemployment rate increased progressively from $18.7 \%$ in the second quarter of 2018 to $19.2 \%$ in the same quarter of 2019 (World Bank, 2019a).

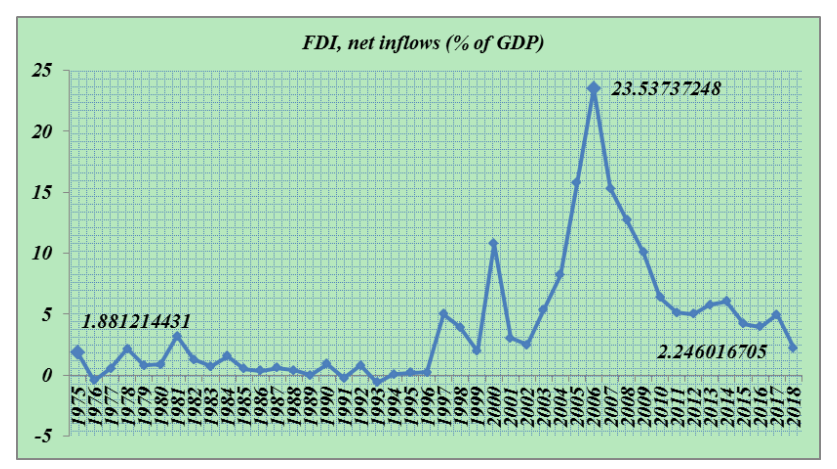

Figure 1. FDI, Net Inflows (\% of GDP) for the Period, 1975-2018

Source: World Bank (2019b).

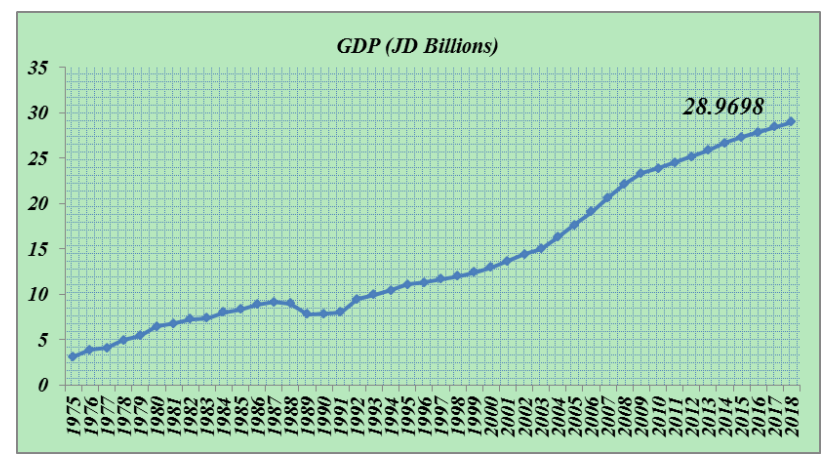

Figure 2. GDP (JD Billions) for the Period, 1975 - 2018

Source: World Bank (2019b).

\section{Methodology and Results Analysis}

The main purpose of this study is to examine co-integration and causal relationships between inward FDI and its determinants in Jordan for (the 1980 - 2018 period). The determinants of inward FDI that have been used in this study are; gross domestic product (GDP), trade openness (TO), education (E), infrastructure (I), and technological capabilities (TC). The justification of using these determinants is based on the type of inward FDI determinants (see Table 1).

The following model explains the determinants of inward FDI in Jordan for (the $1980-2018$ period):

$$
\mathrm{FDI}_{\mathrm{t}}=f\left(\mathrm{GDP}_{\mathrm{t}}, \mathrm{TO}_{\mathrm{t}}, \mathrm{E}_{\mathrm{t}}, \mathrm{I}_{\mathrm{t}}, \mathrm{TC}_{\mathrm{t}}\right)
$$

All the variables in the previous equation are converted into natural logarithms specification to present the following multiple regressions:

$$
\operatorname{LogFDI}_{t}=\alpha_{0}+\alpha_{1} \operatorname{LogGDP}_{t}+\alpha_{2} \operatorname{LogTO}_{t}+\alpha_{3} \log _{t}+\alpha_{4} \operatorname{LogI}_{t}+\alpha_{5} \operatorname{LogTC}_{t}+\varepsilon_{t}
$$

Different econometrics steps are applied to investigate causal and co-integration relationships among inward FDI and its determinants. (1) The stationary properties are examined for each variable. (2) The co-integration status is analyzed to inspect long run relationship among variables. (3) The Granger causality test is used to investigate the causality relationships among variables. Table 2 shows that the null hypothesis of a unit root is overruled at the first difference. Hence, the co-integration is tested between variables using Johansen (1988), and Johansen and Juselius (1990). The outcomes in Table 3 show that the null hypotheses of no cointegration are overruled. The presence of co-integration between variables leads to examine causal relationships via the VECM. This model estimates the 
causality in the short run through the Wald test, while the causality in the long run is done through the error correction term. The multivariate ( $\mathrm{p}$-th) order VECM formulated as follows:

$$
\left[\begin{array}{l}
\Delta \log \left(F D I_{t}\right) \\
\Delta \log \left(G D P_{t}\right) \\
\Delta \log \left(T O_{t}\right) \\
\Delta \log \left(E_{t}\right) \\
\Delta \log \left(I_{t}\right) \\
\Delta \log \left(T C_{t}\right)
\end{array}\right]=\left[\begin{array}{l}
\alpha_{1 t} \\
\alpha_{2 t} \\
\alpha_{3 t} \\
\alpha_{4 t} \\
\alpha_{5 t} \\
\alpha_{6 t}
\end{array}\right]+\sum_{i=1}^{k-1}\left[\begin{array}{l}
\beta_{11 i} \beta_{12 i} \beta_{13 i} \beta_{14 i} \beta_{15 i} \beta_{16 i} \\
\beta_{21 i} \beta_{22 i} \beta_{23 i} \beta_{24 i} \beta_{25 i} \beta_{26 i} \\
\beta_{31 i} \beta_{32 i} \beta_{33 i} \beta_{34 i} \beta_{35 i} \beta_{36 i} \\
\beta_{41 i} \beta_{42 i} \beta_{43 i} \beta_{44 i} \beta_{45 i} \beta_{46 i} \\
\beta_{51 i} \beta_{52 i} \beta_{53 i} \beta_{54 i} \beta_{55 i} \beta_{56 i} \\
\beta_{61 i} \beta_{62 i} \beta_{63 i} \beta_{64 i} \beta_{65 i} \beta_{66 i}
\end{array}\right]\left[\begin{array}{l}
\Delta \log \left(F D I_{t-1}\right) \\
\Delta \log \left(G D P_{t-1}\right) \\
\Delta \log \left(T O_{t-1}\right) \\
\Delta \log \left(E_{t-1}\right) \\
\Delta \log \left(I_{t-1}\right) \\
\Delta \log \left(T C_{t-1}\right)
\end{array}\right]+\left[\begin{array}{l}
\lambda_{1 t} \\
\lambda_{2 t} \\
\lambda_{3 t} \\
\lambda_{4 t} \\
\lambda_{5 t} \\
\lambda_{6 t}
\end{array}\right]\left[E C T_{t-1}\right]+\left[\begin{array}{l}
\varepsilon_{1 t} \\
\varepsilon_{2 t} \\
\varepsilon_{3 t} \\
\varepsilon_{4 t} \\
\varepsilon_{5 t} \\
\varepsilon_{6 t}
\end{array}\right]
$$

Table 1. Variables definitions and sources

\begin{tabular}{|c|c|c|c|c|}
\hline Variable & Notation & $\begin{array}{l}\text { Type of inward FDI } \\
\text { determinant }\end{array}$ & $\begin{array}{l}\text { Expected } \\
\text { effect }\end{array}$ & Source and website \\
\hline Inward FDI (millions JD). & FDI & & & \multirow{6}{*}{$\begin{array}{l}\text { World } \\
(2019 b)\end{array}$} \\
\hline $\begin{array}{l}\text { Gross domestic product, market size } \\
\text { (billions JD). }\end{array}$ & GDP & Seeking of Market & Positive & \\
\hline $\begin{array}{l}\text { Trade openness (sum of exports and } \\
\text { imports) (billions JD). }\end{array}$ & TO & $\begin{array}{l}\text { seeking of Market \& } \\
\text { Efficiency }\end{array}$ & Positive & \\
\hline $\begin{array}{l}\text { Education, school enrollment - } \\
\text { tertiary (\% gross). }\end{array}$ & $\mathrm{E}$ & $\begin{array}{l}\text { seeking of Resource } \\
\text { \& Efficiency }\end{array}$ & Positive & \\
\hline $\begin{array}{l}\text { Infrastructure, Fixed telephone } \\
\text { subscriptions (per } 100 \text { folks). }\end{array}$ & I & $\begin{array}{l}\text { Seeking of Resource } \\
\& \text { Efficiency }\end{array}$ & Positive & \\
\hline $\begin{array}{lrr}\begin{array}{l}\text { Technological } \\
\text { applications }\end{array} & \begin{array}{r}\text { capabilities, } \\
\text { (residents }\end{array} & \text { patent } \\
\text { nonresidents). } & & \end{array}$ & $\mathrm{TC}$ & $\begin{array}{l}\text { seeking } \\
\text { Ownership } \\
\text { advantage }\end{array}$ & Positive & \\
\hline
\end{tabular}

Table 2. Results of time series unit root tests

\begin{tabular}{|c|c|c|c|c|}
\hline & \multicolumn{2}{|c|}{$\mathrm{Ng} \&$ Perron } & \multicolumn{2}{|c|}{ DF \& GLS } \\
\hline & Constant & Constant \& trend & Constant & Constant \& trend \\
\hline Variables & Statistics & Statistics & Statistics & Statistics \\
\hline \multicolumn{5}{|l|}{ At levels } \\
\hline $\operatorname{LogFDI}_{t}$ & -4.200 & -12.32 & -0.801 & -2.344 \\
\hline $\operatorname{LogGDP}_{t}$ & -3.123 & -13.21 & -0.823 & -2.112 \\
\hline${\log \mathrm{TO}_{\mathrm{t}}}$ & -3.543 & -16.21 & -1.211 & -2.000 \\
\hline $\log E_{t}$ & -5.252 & -16.46 & -1.341 & -1.544 \\
\hline $\log _{t}$ & -6.234 & -15.56 & -1.101 & -1.589 \\
\hline${\log T C_{t}}_{t}$ & -6.341 & -11.23 & -1.466 & -2.455 \\
\hline \multicolumn{5}{|c|}{ At the first difference } \\
\hline$\Delta \operatorname{LogFDI}_{t}$ & $-7.211^{*}$ & $-18.23^{*}$ & $-2.565^{*}$ & $-5.122^{* * * *}$ \\
\hline$\Delta \operatorname{LogGDP}_{t}$ & $-10.45^{* *}$ & $-20.45^{* *}$ & $-5.678^{* * * *}$ & $-3.789^{* * *}$ \\
\hline$\Delta \log \mathrm{TO}_{\mathrm{t}}$ & $-8.345^{*}$ & $-28.12^{* * *}$ & $-3.456^{* *}$ & $-3.344^{* * *}$ \\
\hline$\Delta \log E_{t}$ & $-15.10^{* * *}$ & $-22.50^{* *}$ & $-4.888^{* * * *}$ & $-6.123^{* * * *}$ \\
\hline
\end{tabular}




\begin{tabular}{lllll}
\hline$\Delta \operatorname{LogI}_{\mathrm{t}}$ & $-10.23^{* *}$ & $-29.10^{* * * *}$ & $-2.459^{*}$ & $-4.156^{* *}$ \\
\hline$\Delta \log _{\mathrm{TC}}$ & $-8.100^{*}$ & $-24.50^{* *}$ & $-2.623^{*}$ & $-3.339^{* *}$ \\
\hline & Critical values of the Ng \& Perron (MZa) test & \multicolumn{1}{c}{ Critical values of the (DF \& GLS) test } \\
\hline & Constant & Constant \& trend & Constant & Constant \& trend \\
\hline $1 \%$ & -14.90 & -26.90 & -4.643 & -4.870 \\
\hline $5 \%$ & -9.200 & -19.60 & -2.954 & -3.200 \\
\hline $10 \%$ & -6.900 & -17.30 & -1.911 & -2.991 \\
\hline
\end{tabular}

Notes: (a) DF-GLS introduced by, Ng and Perron (2001) and Elliot et al. (1996).

(b) ${ }^{* * *}, * *$ and ${ }^{*}$ denote the significance at: $(1 \%, 5 \%, \& 10 \%)$ levels, respectively.

(c) Source: author's calculation by using the software of Eviews 12 .

Table 3. Results of time series co-integration test

\begin{tabular}{lllllll}
\hline & \multicolumn{2}{l}{ Trace statistics } & \multicolumn{3}{l}{ Maximal Eigen values } \\
\hline $\begin{array}{l}\text { Null } \\
\text { hypothesis }\end{array}$ & $\begin{array}{l}\text { value } \\
\text { statistics }\end{array}$ & $\begin{array}{l}5 \% \text { critical } \\
\text { values }\end{array}$ & P-values & $\begin{array}{l}\text { value } \\
\text { statistics }\end{array}$ & $\begin{array}{l}5 \% \text { critical } \\
\text { values }\end{array}$ & P-values \\
\hline $\mathrm{r}=0$ & 309.23 & 213.46 & $0.04^{* *}$ & 210.12 & 190.23 & $0.03^{* *}$ \\
\hline $\mathrm{r} \leq 1$ & 210.45 & 195.45 & $0.03^{* *}$ & 151.21 & 139.10 & $0.02^{* *}$ \\
\hline $\mathrm{r} \leq 1$ & 190.34 & 160.21 & $0.02^{* *}$ & 131.10 & 110.23 & $0.04^{* *}$ \\
\hline $\mathrm{r} \leq 1$ & 100.67 & 92.231 & $0.03^{* *}$ & 98.231 & 92.112 & $0.05^{* *}$ \\
\hline $\mathrm{r} \leq 1$ & 68.901 & 61.134 & $0.05^{* *}$ & 71.101 & 66.789 & $0.02^{* *}$ \\
\hline $\mathrm{r} \leq 1$ & 52.345 & 43.101 & $0.05^{* *}$ & 51.231 & 44.124 & $0.03^{* *}$
\end{tabular}

Notes: (a) ${ }^{* *}$ denotes the significance at: the (5\%) level.

(b) $r$ represents the number of cointegrating relationship among variables.

(c) The lag length, $\mathrm{k}=3$, is determined by the Akaike Information Criterion, AIC.

(d) Source: author's calculation by using the software of Eviews 12 .

Table 4. Results of time series VECM (Dependent variable is $\Delta \operatorname{LogFDI}_{t}$ )

\begin{tabular}{|c|c|c|c|c|}
\hline & \multicolumn{2}{|c|}{ Short term; Wald test - F-statistics values } & \multicolumn{2}{|l|}{ Diagnostic tests values } \\
\hline & Coefficient & $\mathrm{P}$-value & Test & Value \\
\hline$\Delta \operatorname{LogGDP}_{\mathrm{t}}$ & 0.301 & $0.001^{* * * *}$ & \multirow{2}{*}{$\mathrm{R}^{2}$} & \multirow{2}{*}{0.81} \\
\hline$\Delta \operatorname{LogTO}_{\mathrm{t}}$ & 0.213 & $0.043^{* *}$ & & \\
\hline$\Delta \log E_{t}$ & 0.431 & $0.001^{* * * *}$ & \multirow{3}{*}{ F-statistics value } & \multirow{3}{*}{$619(0.00)$} \\
\hline$\Delta \log I_{t}$ & 0.335 & $0.002^{* * *}$ & & \\
\hline$\Delta \operatorname{LogTC}_{t}$ & 0.456 & $0.001^{* * *}$ & & \\
\hline \multicolumn{5}{|c|}{ Long term; t-statistics values } \\
\hline & Coefficient & $\mathrm{P}$-value & \multirow{2}{*}{ Normality test (Jarque Bera) } & \multirow{2}{*}{$1.342(0.211)$} \\
\hline $\mathrm{ECT}_{\mathrm{t}-1}$ & -0.821 & $0.001^{* * *}$ & & \\
\hline
\end{tabular}


Table 4 reported the results regarding the VECM Granger causality test in (long term and short term), where FDI is the dependent variable. Starting with the long term results, the coefficient of the lagged error correction, -0.821 , is statistically significant at the $1 \%$ level. Thus, there is a long term causality running from each of gross domestic product, education, trade openness, infrastructure, and technological abilities to inward FDI. Checking out the short term side, there is a causality direction from all variables to inward FDI.

\section{Summary and Policy Implications}

The current paper applied the VECM to examine causal links, long term and short term between inward FDI and its determinants in Jordan for (the 1980 - 2018 period). The findings indicated that gross domestic product (market size), trade openness (exports \& imports), education (school enrollment), infrastructure (fixed telephone subscriptions), and technological capabilities (patent applications) stimulate inward FDI in Jordan. In other words, these variables are important drivers for inward FDI in long term and short term. Hence, it is important for legislators in Jordan to adopt national policies which advance the ability of educated local labor force, increase the economic development, and improve infrastructure abilities. In addition, legislators in Jordan should concentrate on removing trade obstacles through establishing a mutual connection between government authorities and entities of foreign private investments.

\section{References}

Abdouli, M., \& Hammami, S. (2017). Investigating the causality links between environmental quality, foreign direct investment and economic growth in MENA countries. International Business Review, 26(2), 264-278. https://doi.org/10.1016/j.ibusrev.2016.07.004

Beckmann, J., \& Czudaj, R. (2017). Capital flows and GDP in emerging economies and the role of global spillovers. Journal of Economic Behavior \& Organization, 142, 140-163. https://doi.org/10.1016/j.jebo.2017.07.031

Bekhet, H. A., \& Al-Smadi, R. W. (2015). Determinants of Jordanian foreign direct investment inflows: bounds testing approach. Economic Modelling, 46, 27-35. https://doi.org/10.1016/j.econmod.2014.12.027

Belloumi, M. (2014). The relationship between trade, FDI and economic growth in Tunisia: An application of the autoregressive distributed lag model. Economic Systems, 38, 269-287. https://doi.org/10.1016/j.ecosys.2013.09.002

Bilgili, F., Tuluce, N. S. H., \& Dogan, I. (2012). The determinants of FDI in Turkey: A markov regime-switching approach. Economic Modelling, 29, 1161-1169. https://doi.org/10.1016/j.econmod.2012.04.009

Boateng, A., Hua, X., Nisar, S., \& Wu, J. (2015). Examining the determinants of inward FDI: Evidence from Norway. Economic Modelling, 47, 118-127. https://doi.org/10.1016/j.econmod.2015.02.018

Cui, L., \& Xu, Y. (2019). Outward FDI and profitability of emerging economy firms: diversifying from home resource dependence in early stage internationalization. Journal of World Business, 54(4), 372-386. https://doi.org/10.1016/j.jwb.2019.04.002

Dellis, K., Sondermann, D., \& Vansteenkiste, I. (2020). Drivers of genuine FDI inflows in advanced economies. The Quarterly Review of Economics and Finance. https://doi.org/10.1016/j.qref.2020.09.004

Dunning, J. H. (1993). Internationalizing porter's diamond. MIR: Management International Review, 33(2), 7-15.

Economou, F. (2019). Economic freedom and asymmetric crisis effects on FDI inflows: the case of four South European economies. Research in International Business and Finance, 49, 114-126. https://doi.org/10.1016/j.ribaf.2019.02.011

Elheddad, M. M. (2018). What determines FDI inflow to MENA countries? Empirical study on Gulf countries: Sectoral level analysis. Research in International Business and Finance, 44, 332-339. https://doi.org/10.1016/j.ribaf.2017.07.101

Elliot, G., Rothenberg, T. J., \& Stock, J. H. (1996). Efficient tests for an autoregressive unit root. Econometrica, 64(4), 813-836. https://doi.org/10.2307/2171846

Hou, L., Li, K., Li, Q., \& Ouyang, M. (2020). Revisiting the location of FDI in China: A panel data approach with heterogeneous shocks. Journal of Econometrics. https://doi.org/10.1016/j.jeconom.2020.04.047

Iwasaki, I., \& Tokunaga, M. (2016). Technology transfer and spillovers from FDI in transition economies: A meta-analysis. Journal of Comparative Economics, 44(4), 1086-1114. https://doi.org/10.1016/j.jce.2016.10.005

Johansen, S. (1988). Statistical analysis of cointegration vectors. Journal of Economic Dynamics and Control, 12(2-3), 231-254. https://doi.org/10.1016/0165-1889(88)90041-3 
Johansen, S., \& Juselius, K. (1990). Maximum likelihood estimation and inference on cointegration - with applications to the demand for money. Oxford Bulletin of Economics and Statistics, 52(2), 169-210. https://doi.org/10.1111/j.1468-0084.1990.mp52002003.x

Kayalvizhi, P. N., \& Thenmozhi, M. (2018). Does quality of innovation, culture and governance drive FDI? Evidence from emerging markets. Emerging Markets Review, 34, 175-191. https://doi.org/10.1016/j.ememar.2017.11.007

Kinuthia, B. K., \& Murshed, S. M. (2015). FDI determinants: Kenya and Malaysia compared. Journal of Policy Modeling, 37(2), 388-400. https://doi.org/10.1016/j.jpolmod.2015.01.013

Lee, M., Alba, J. D., \& Park, D. (2018). Intellectual property rights, informal economy, and FDI into developing countries. Journal of Policy Modeling, 40(5), 1067-1081. https://doi.org/10.1016/j.jpolmod.2018.07.003

Li, X., Quan, R., Stonia, M. C., \& Azar, G. (2018). Do MNEs from developed and emerging economies differ in their location choice of FDI? A 36-year review. International Business Review, 27(5), 1089-1103. https://doi.org/10.1016/j.ibusrev.2018.03.012

Lien, Y. C., \& Filatotcher, I. (2015). Ownership characterstics as determinants of FDI location decisions in emerging economies. Journal of World Business, 50(4), 637-650. https://doi.org/10.1016/j.jwb.2014.09.002

Muhammad, B., \& Khan, S. (2019). Effects of bilateral FDI, energy consumption, CO2 emission and capital on economic growth of Asia countries. Energy Reports, 5, 1305-1315. https://doi.org/10.1016/j.egyr.2019.09.004

Ng, S., \& Perron, P. (2001). Lag length selection and the construction of unit root test with good size and power. Econometrica, 69(6), 1519-1554. https://doi.org/10.1111/1468-0262.00256

Sadeghi, P., Shahresani, H., Kiani, K. H., \& Torabi, T. (2020). Economic complexity, human capital, and FDI attraction: A cross country analysis. International Economics, 164, 168-182. https://doi.org/10.1016/j.inteco.2020.08.005

Tsitouras, A., Mitrakos, P., Tsimpida, C., Vlachos, V., \& Bitzenis, A. (2019). An investigation into the causal links among FDI determinants: Empirical evidence from Greece. Journal of East-West Business, 25(4), 1-39. https://doi.org/10.1080/10669868.2019.1640829

Vo, X. V. (2018). Determinants of capital flows to emerging economies-evidence from Vietnam. Finance Research Letters, 27, 23-27. https://doi.org/10.1016/j.frl.2018.02.031

World Bank. (2019a). Jordan at a glance. Retrieved November 20, 2019, from https://www.worldbank.org/en/country/jordan/overview

World Bank. (2019b). Annual time series data. Retrieved November 20, 2019, from https://data.worldbank.org/country/jordan

\section{Copyrights}

Copyright for this article is retained by the author(s), with first publication rights granted to the journal.

This is an open-access article distributed under the terms and conditions of the Creative Commons Attribution license (http://creativecommons.org/licenses/by/4.0/). 